\title{
Remedial effect of ascorbic acid and citric acid on oxidative browning of Glycyrrhiza glabra callus cultures
}

\author{
U. ViJayalakshmi, Abhilasha Shourie* \\ Department of Biotechnology, Faculty of Engineering and Technology, \\ Manav Rachna International University, Faridabad, India
}

\begin{abstract}
Oxidative browning is a common and severe problem in plant tissue cultures including callus cultures of Glycyrrhiza glabra, where browning is caused by accumulation and oxidation of phenolic compounds. Brown callus results in decreased biosynthetic potential and poor growth, eventually leading to cell death. In this study, the effect of different concentrations and combinations of antioxidants - ascorbic acid, and citric acid on browning of G.glabra callus was studied. Morphological and ultra-structural changes related to browning and antioxidant treatment were also studied using scanning electron microscopy (SEM) and transmission electron microscopy (TEM) to evaluate the cellular characteristics and metabolic activity of control and treated callus. Intensity of browning in callus remarkably decreased with increasing concentrations of ascorbic acid; the browning was completely overcome at a concentration of $20 \mathrm{mg} / 1$ ascorbic acid, in combination with $10 \mathrm{mg} / 1$ citric acid. An electron microscopy analysis showed that brown callus was found to have ruptured cell surface and a disorganized cell structure with the absence of cell organelles that affected callus development and lead to cell death. Non-brown callus had all the characteristics typical for a non-embryogenic callus cells with high-level activity showing all vital cell organelles including abundant and elongated mitochondria. Therefore, we conclude that ascorbic acid and citric acid have wide applications in tissue cultures of Glycyrrhiza glabra where browning restricts the callus development, and lead to the establishment of non-embryogenic callus with high metabolic activity for further use in secondary metabolite production.
\end{abstract}

Key words: callus, browning, ascorbic acid, citric acid, Glycyrrhiza glabra

\section{Introduction}

Glycyrrhiza glabra is a medicinal plant that has been used for thousands of years in folk remedies. It has a wide range of secondary metabolites (Vijayalakshmi and Shourie, 2013) and is well known for its pharmaceutical properties. Tissue cultures of Glycyrrhiza glabra can be seen as an efficient system for the in vitro production of valuable secondary metabolites. In production of secondary metabolites, the callus culture remains the primary step for a subsequent plant cell culture. Callus cultures may be embryogenic or non-embryogenic. Nonembryogenic callus cultures, containing more or less homogenous clumps of dedifferentiated cells, are mostly used for secondary metabolite production (Jedinak et al.,
2004). Although work concerning in vitro cell and tissue cultures has been extensively reported on other Glycyrrhiza species (Yu, 1999; Huo et al., 2005; Mousa et al., 2006; Sawaengsak et al., 2011), information on callus induction on Glycyrrhiza glabra is limited (Sharma et al., 2005; Wongwicha et al., 2008; Fu et al., 2010).

During the in vitro callus culture of Glycyrrhiza glabra, severe browning of callus tissue is often observed, which is considered as one of the most interfering phenomena in tissue culture studies and a serious impediment during the mass production of secondary metabolites. Browning is related to enhanced phenolic compound accumulation and their oxidation which involves many toxic compounds, eventually resulting in cell necro- 
sis (Khosroushahi et al., 2011). This led us to study the effect of two antioxidants (ascorbic acid and citric acid) in controlling the browning and promoting callus growth.

Further investigation on the ultra-structure of $G$. glabracallus was carried out using scanning electron microscopy and transmission electron microscopy to study the cellular and ultra-structural changes related to browning and antioxidant treatment under optimized culture conditions and to evaluate the cellular characteristics and metabolic activity of the control and treated callus. Thus, our work aimed to study the effect of antioxidants on browning and to establish well grown, metabolically active non-brown callus from leaf explants of G. glabra.

\section{Materials and methods}

\section{Plant material}

Glycyrrhiza glabra plantlets were obtained from Jamia Humdard University, New Delhi. Young leaves and stems were excised from the plant and were initially washed under running tap water. Then, the surface sterilization procedure for the explants was carried out according to Vijayalakshmi and Shourie (2015).

\section{Media preparation}

The culture medium used for the callus induction was Murashige and Skoog (1962 Basal medium). The medium was prepared by suspending $42.08 \mathrm{~g}$ of MS basal medium (PT011-Himedia), which contains all macro and micro nutrients, in $600 \mathrm{ml}$ of distilled water. Calcium chloride $440 \mathrm{mg}$ was added to the medium. The final volume was made up to $1000 \mathrm{ml}$ with distilled water. The medium was boiled to dissolve agar completely and was sterilized by autoclaving at $15 \mathrm{lbs}$ or $121^{\circ} \mathrm{C}$ for $15 \mathrm{~min}$. The autoclaved medium was cooled to $45^{\circ} \mathrm{C}$ before adding the filter sterilized heat labile supplements. Stock solutions of growth hormones were prepared and filter sterilized using Whatman filter paper and a syringe filter. The MS medium was further supplemented with $0.5 \mathrm{mg} / 16$-benzyl amino purine (6-BAP) and $1 \mathrm{mg} / \mathrm{l}$ naphthalene-3-acetic acid (NAA), which is designated as the basal culture medium for all treatments.

\section{Media supplementation with antioxidants}

In the MS basal medium (Murashige and Skoog, 1962), sterile ascorbic acid solutions of 5,10 , and $20 \mathrm{mg} / \mathrm{l}$ were combined with different concentrations of citric acid (5 and $10 \mathrm{mg} / \mathrm{l}$ ) and the $\mathrm{pH}$ was adjusted to 5.5 using $1 \mathrm{~N} \mathrm{HCl} / \mathrm{NaOH}$. A callus cultured on a medium free from any antioxidants served as the control.

\section{In vitro callus induction and subculture}

The explants were inoculated into the sterilized media. All the inoculations were carried out in a laminar air flow chamber and the cultures were incubated for $16 \mathrm{~h} \mathrm{light} / 8 \mathrm{~h}$ dark photoperiod at $25 \pm 2{ }^{\circ} \mathrm{C}$ under controlled light intensity of 2000 Lux. The developed callus was subcultured at regular intervals and was assessed every week for 6 weeks by measuring the weight of leaf sections initially at the time of inoculation (initial weight) and at the end of each week (weight at week $n$ ) after inoculation. Callus growth was expressed in dry weight. The growth index (GI) was calculated as GI = (final dry weight - initial dry weight) / initial dry weight. All values represent means \pm standard deviation (SD) for 20 cultures per treatment.

\section{Polyphenoloxidase activity}

The assay of polyphenoloxidase activity was carried out for control and treated callus samples after 6 weeks of culture according to Mayer et al. (1965). One gram of 6-week-old callus was homogenized in $2 \mathrm{ml}$ of $0.1 \mathrm{M}$ sodium phosphate buffer $(\mathrm{pH} 6.5)$ at $4^{\circ} \mathrm{C}$. The homogenate was centrifuged at $20000 \mathrm{rpm}$ for $15 \mathrm{~min}$. The supernatant served as enzyme source and polyphenoloxidase activity was determined as described below. The reaction mixture consisted of $1.5 \mathrm{ml}$ of $0.1 \mathrm{M}$ sodium phosphate buffer ( $\mathrm{pH} 6.5)$ and $200 \mu \mathrm{l}$ of the enzyme extract. To start the reaction, $200 \mu \mathrm{l}$ of $0.1 \mathrm{M}$ catechol was added and the polyphenoloxidase activity was expressed as a change in absorbance $\mathrm{min}^{-1} \mathrm{mg}^{-1}$ of protein at $495 \mathrm{~nm}$ at $30 \mathrm{~s}$ intervals for $5 \mathrm{~min}$. The protein content was determined according to the Bradford (1976) method with a standard curve prepared using bovine serum albumin. All experiments were performed in triplicate and the results were expressed as mean value $\pm \mathrm{SD}(n=3)$.

\section{Scanning electron microscopy (SEM)}

The callus samples were collected and fixed in Karnovsky solution (2.5\% glutaraldehyde and $2 \%$ paraformaldehyde) made in $0.1 \mathrm{M}$ sodium phosphate buffer (pH 7.2) for $24 \mathrm{~h}$ at $4{ }^{\circ} \mathrm{C}$ and were later cut into sections 
Table 1. Effect of antioxidants on browning of Glycyrrhiza glabra callus established from leaf explants

\begin{tabular}{|c|c|c|c|c|c|}
\hline \multicolumn{2}{|c|}{ Antioxidant treatments } & \multicolumn{3}{|c|}{ Growth index of callus } & \multirow[b]{2}{*}{ Effect on browning } \\
\hline $\begin{array}{l}\text { ascorbic acid } \\
(\mathrm{mg} / \mathrm{l})\end{array}$ & $\begin{array}{l}\text { citric acid } \\
(\mathrm{mg} / \mathrm{l})\end{array}$ & week 2 & week 4 & week 6 & \\
\hline 0 & 0 & $3.22 \pm 1.08$ & $0.82 \pm 1.64$ & $8.96 \pm 3.07$ & intense browning \\
\hline 5 & 5 & $3.21 \pm 1.14$ & $5.23 \pm 1.45$ & $8.55 \pm 2.81$ & no change in the intensity of browning \\
\hline 10 & 5 & $3.04 \pm 0.98$ & $5.93 \pm 1.98$ & $8.79 \pm 2.67$ & slight change in brown color \\
\hline 5 & 10 & $3.12 \pm 0.87$ & $6.72 \pm 2.01$ & $9.37 \pm 2.76$ & lesser browning \\
\hline 10 & 10 & $3.14 \pm 1.06$ & $6.78 \pm 1.98$ & $9.41 \pm 3.13$ & very little browning \\
\hline 20 & 10 & $3.16 \pm 1.21$ & $6.75 \pm 2.09$ & $9.42 \pm 3.21$ & no browning, cream color callus \\
\hline
\end{tabular}

of $1 \mathrm{~mm}$ thickness with scalpel and then washed with phosphate buffer three times. Then, the fragments were dehydrated and subjected to complete drying. The samples were then mounted on aluminum stubs coated with gold and were observed in Zeiss EV 040 scanning electron microscope (Advanced Instrumentation Research Facility (AIRF), JNU, New Delhi).

\section{Transmission electron microscopy (TEM)}

The callus samples were collected and fixed in Karnovsky solution (2.5\% glutaraldehyde and $2 \%$ paraformaldehyde) made in $0.1 \mathrm{M}$ sodium phosphate buffer ( $\mathrm{pH} 7.2$ ) for $24 \mathrm{~h}$ at $4{ }^{\circ} \mathrm{C}$, then were cut into sections of $1 \mathrm{~cm}^{3}$ thickness with a scalpel and washed with phosphate buffer three times. The fixed samples were taken to the Advanced Instrumentation Research Facility, JNU, New Delhi, for further processing and the images captured with JEOL $2100 \mathrm{~F}$ transmission electron microscopy were used to study the ultra-structure of the callus.

\section{Results and discussion}

\section{Effect of antioxidants on browning}

Our experimental results revealed that almost all the calli grown on the control medium showed excessive browning and were soon after observed to be declining. This led to the deterioration of the callus with a loss of morphogenetic and biosynthetic potential. The appearance of browning and necrosis of callus tissues at various stages of growth and differentiation is one of the major reasons causing poor callus growth response, usually resulting in restricted metabolic activity. Browning of the tissue is correlated with excessive accumulation of phenolic compounds and their subsequent oxi

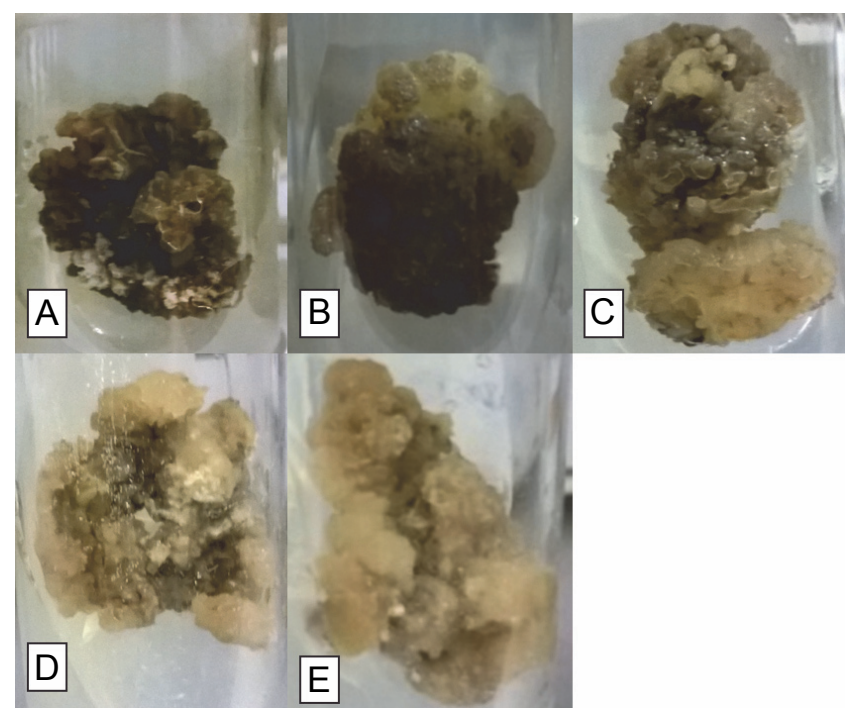

Fig. 1. Effect of antioxidants on the intensity of callus browning; a) Control b) $10 \mathrm{mg} / 1 \mathrm{AA}$ and $5 \mathrm{mg} / \mathrm{l} \mathrm{CA}$, c) $5 \mathrm{mg} / \mathrm{l} \mathrm{AA}$ and $10 \mathrm{mg} / \mathrm{l} \mathrm{CA}$, d) $10 \mathrm{mg} / 1 \mathrm{AA}$ and $10 \mathrm{mg} / \mathrm{l} \mathrm{CA}$, e) $20 \mathrm{mg} / \mathrm{l} \mathrm{AA}$ and $10 \mathrm{mg} / \mathrm{l} \mathrm{CA}$ (AA - ascorbic acid, CA - citric acid)

dation. Glycyrrhiza glabra is a good source of a large number of phenolic compounds of high pharmaceutical value and tissue cultures of this plant are used for their production (Vijayalakshmi and Shourie, 2015). Therefore, the oxidation of phenolic compounds not only leads to browning and cell death but also reduces the yield of phenolic compounds in callus by lowering its biosynthetic capacity. Various methods have been used to overcome the problem of browning. In our study, different concentrations and combinations of ascorbic acid and citric acid were tested to inhibit callus browning.

At lower concentrations of antioxidants there was no change in the browning intensity of callus. The combination of $10 \mathrm{mg} / \mathrm{l}$ citric acid with 5,10 , and $20 \mathrm{mg} / \mathrm{l}$ as- 
corbic acid was found effective in reducing the intensity of brown color (Table 1). The browning decreased with increasing concentrations of ascorbic acid and it was seen that the $20 \mathrm{mg} / \mathrm{l}$ ascorbic acid in combination with $10 \mathrm{mg} / \mathrm{l}$ citric acid was much more effective in the reduction of callus browning as compared to other combinations (Fig. 1). At this concentration, the browning was fully overcome and a light cream fragile callus was obtained. Concentrations of ascorbic acid higher than $20 \mathrm{mg} / \mathrm{l} \mathrm{had} \mathrm{a} \mathrm{similar} \mathrm{effect} \mathrm{on} \mathrm{browning} \mathrm{but} \mathrm{led} \mathrm{to} \mathrm{a} \mathrm{de-}$ crease in the growth index of the callus. Therefore, this antioxidant concentration and combination $(20 \mathrm{mg} / \mathrm{l}$ ascorbic acid and $10 \mathrm{mg} / 1$ citric acid) was deduced to be the optimum concentration for reducing oxidation of phenolic compounds in callus cultures of G. glabra.

Ascorbic acid has been successfully used in the past to inhibit or reduce oxidative browning in callus cultures of various plant species (Banerjee et al., 1996; Habibi et al., 2009). Ascorbic acid can scavenge oxygen radicals produced when the plant tissue is wounded, therefore protecting the cells from oxidative injury. A reduced form of ascorbic acid is oxidized to form dehydroascorbic acid which reduces oxygen in its surroundings, making ascorbic acid an effective antioxidant.

Browning occurs when polyphenoloxidases (PPO) catalyze the oxidation of phenols to form compounds called quinones (Dehon et al., 2002). Quinones can then polymerize to form melanins (brown pigments). In the presence of metalions, phenols can readily convert into quinones. By chelating metal ions, ascorbic acid can make each compound unavailable for reacting with phenols and thus prevents the conversion of phenols to quinones (Flora, 2009).

Also, because polyphenolases are most active in a pH range between 5.8 and 7.0, combinations of ascorbic acid and citric acid are sometimes used to prevent browning by reducing the $\mathrm{pH}$ below the optimum level for the enzyme (polyphenoloxidase) to catalyze the oxidative enzymatic browning reaction and thus diminishing the enzyme activity. In this study, the polyphenoloxidase activity was found to be decreasing with higher concentrations of ascorbic acid and citric acid to a statistically significant level (at $\alpha=0.05$ ) as compared to that of the control (Fig. 2). Maximum inhibition of the PPO activity occurred in a callus grown on media with $20 \mathrm{mg} / \mathrm{l}$ ascorbic acid and $10 \mathrm{mg} / \mathrm{l}$ citric acid. Therefore, it can be said that these antioxidants are useful and effective in

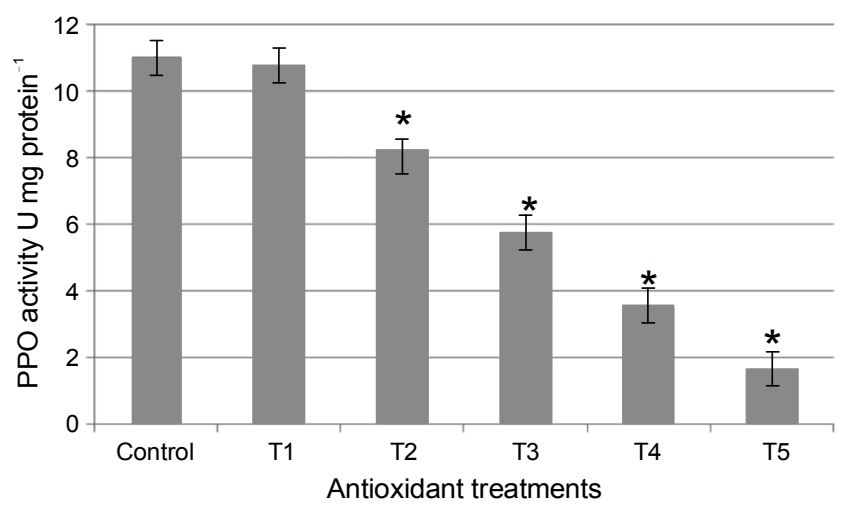

Fig. 2. Effect of antioxidant treatment on polyphenoloxidase activity; T1 $=10 \mathrm{mg} / \mathrm{l} \mathrm{AA}$ and $5 \mathrm{mg} / 1 \mathrm{CA}, \mathrm{T} 2=5 \mathrm{mg} / \mathrm{l} \mathrm{AA}$ and $10 \mathrm{mg} / \mathrm{l} \mathrm{CA}, \mathrm{T} 3=10 \mathrm{mg} / \mathrm{l} \mathrm{AA}$ and $10 \mathrm{mg} / \mathrm{l} \mathrm{CA}, \mathrm{T} 4=10 \mathrm{mg} / \mathrm{l}$ $\mathrm{AA}$ and $10 \mathrm{mg} / \mathrm{l} \mathrm{CA}, \mathrm{T} 5=20 \mathrm{mg} / \mathrm{AA}$ and $10 \mathrm{mg} / \mathrm{l} \mathrm{CA}$ (AA - ascorbic acid, CA - citric acid).Values marked with (*) are significantly different from the control at $\alpha=0.05$

managing the problem of phenolic compounds and improving plant growth in vitro which in turn helps to keep the biosynthetic potential of the callus, leading to an effective production of medicinally valuable phenolic compounds.

\section{Morphological and ultra-structural analysis}

An in vitro tissue culture induces different cellular responses that mediate adaptation under new culture conditions. Brown and non-brown callus cells differ from each other in several ways. Similarly, highly active and proliferating cells have their unique characteristics such as intense synthesis of RNA and extensive metabolic activity. These characteristics can be analyzed morphologically and ultra-structurally by using microscopic techniques (Aslam et al., 2011). In this study, many features were identified through scanning electron microscopy (SEM) and transmission electron microscopy (TEM) to differentiate between the control (brown) and the treated (non-brown) callus and to confirm whether the callus obtained was of high metabolic activity and proliferation rate.

It was observed through scanning electron microscopy that cells from non-brown callus of $G$. glabra were arranged in clusters having number of convoluted long cells (Fig. 3A). The elongated, curled tubular structure of these cells can be clearly seen at higher magnifications (Fig. 3B). According to Ribeiro et al. (2012) such cells are seen in non-embryogenic callus. Cells with such morphology were also observed by other researchers in the callus of different plants. Chaudhury and $\mathrm{Qu}(2000)$ 

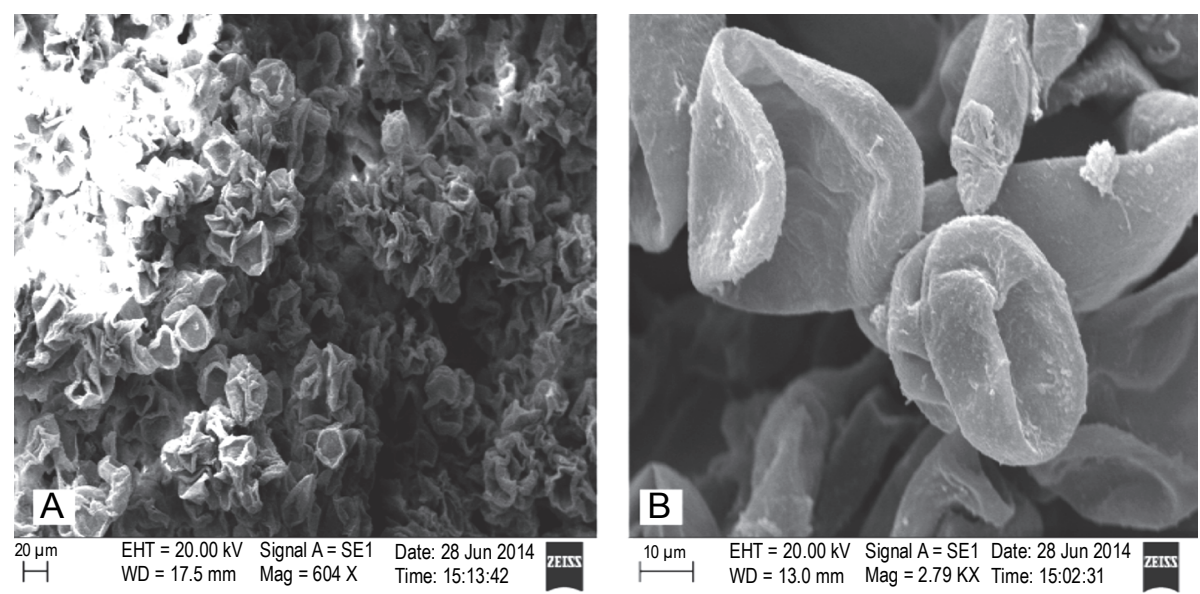

Fig. 3. Scanning electron micrograph of non-brown callus cultured in MS media with $1 \mathrm{mg} / 1 \mathrm{NAA}$ and $0.5 \mathrm{mg} / 1 \mathrm{BAP}$ and antioxidants. A) cells arranged in clusters, B) a magnified image of a cell showing a fully elongated tubular structure
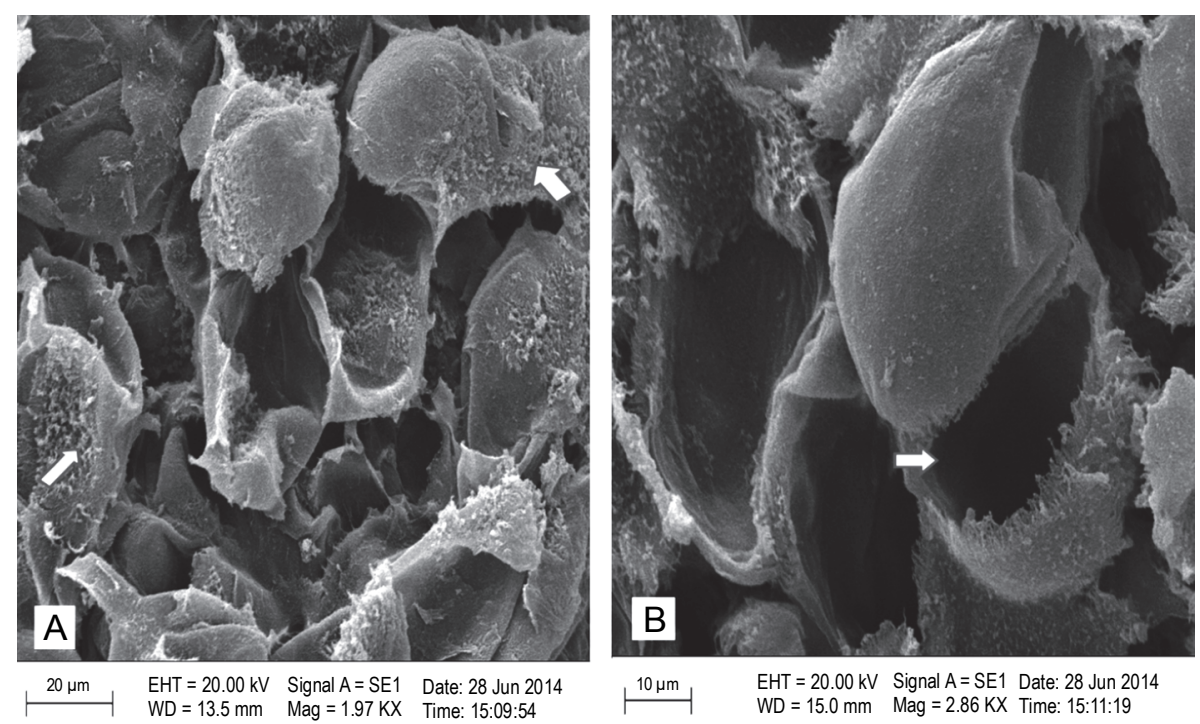

Fig. 4. SEM image of cells of a brown callus showing A) cells with a scattered uneven structure having much debris (marked with arrows), B) a magnified image of a ruptured cell on callus surface marked with an arrow

reported that non-embryogenic callus cultures of Bermuda grass had elongated and tubular cells with a disorganized structure. Figueiredo et al. (2007) also observed non-embryogenic callus cells that were elongated in shape but were poorly organized. Whereas, Hossain et al. (2009) noticed two distinct morphologies showing isodiametric as well as elongated cells in embryogenic suspensions of Musa (Banana). This shows that the nonbrown callus obtained under optimized conditions shows the characteristics of a non-embryogenic callus.

Scanning electron microscopy also revealed several other features of interest, the non-brown callus cells were having smooth surface with little or no debris. In contrast, a brown callus was found to have loss of uneven cells with scattered arrangement and much debris (Fig. 4A), some of which looked like ruptures on the surface (Fig. 4B) that affected callus development leading to cell death. These results were similar to those observed by He et al. (2009) in the brown callus of Jatropacurcas.

TEM analysis of a non-brown callus of Glycyrrhiza glabra showed the presence of cells lying next to one another separated by a thin cell wall. The cells had dense cytoplasm compressed against the cell wall due to the presence of large vacuoles (Fig. 5A). Canhoto et al. (1996) and Uddain et al. (2015) also observed cytoplasm compression by vacuole in pineapple guava cells and J. curcas cells, respectively. The ultra-structure of non- 

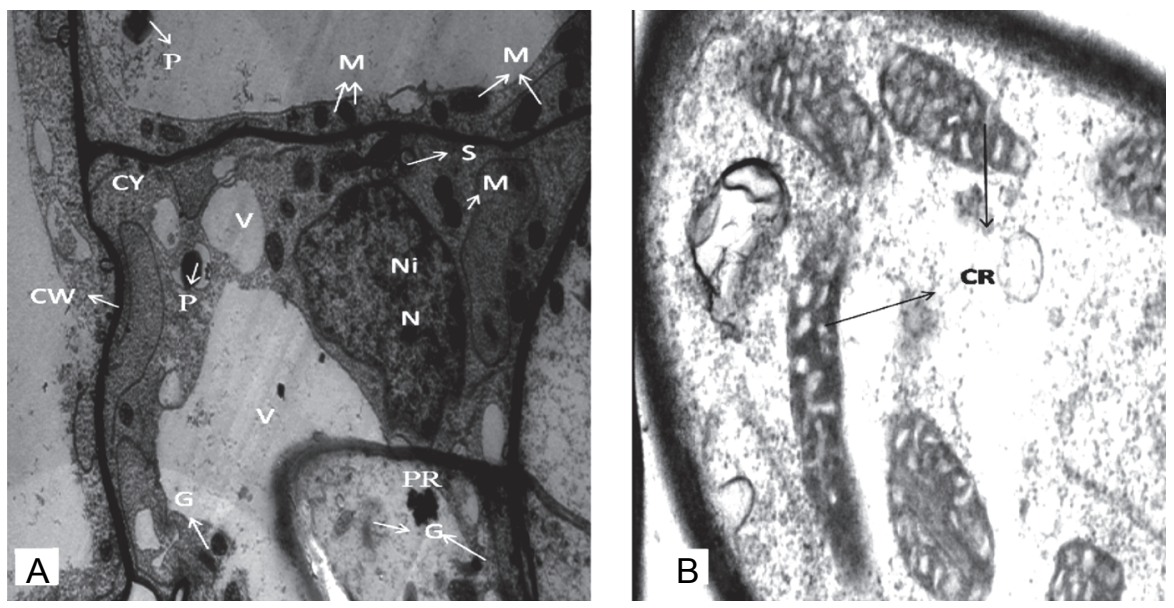

Fig. 5. Transmission electron microscopy image of a non-brown callus a) Cells with a thin cell wall, dense cytoplasm (CY), nucleus $(\mathrm{N})$, nucleoli $(\mathrm{Ni})$ vacuole $(\mathrm{V})$, plastids $(\mathrm{P})$, Golgi bodies $(\mathrm{G})$,starch granules $(\mathrm{S})$, poly-ribosomes $(\mathrm{PR})$, and abundant mitochondria (M), b) a magnified image of a portion of a cell showing a fully developed structure of mitochondria with clearly visible mitochondrial cristae (CR) marked with black arrows
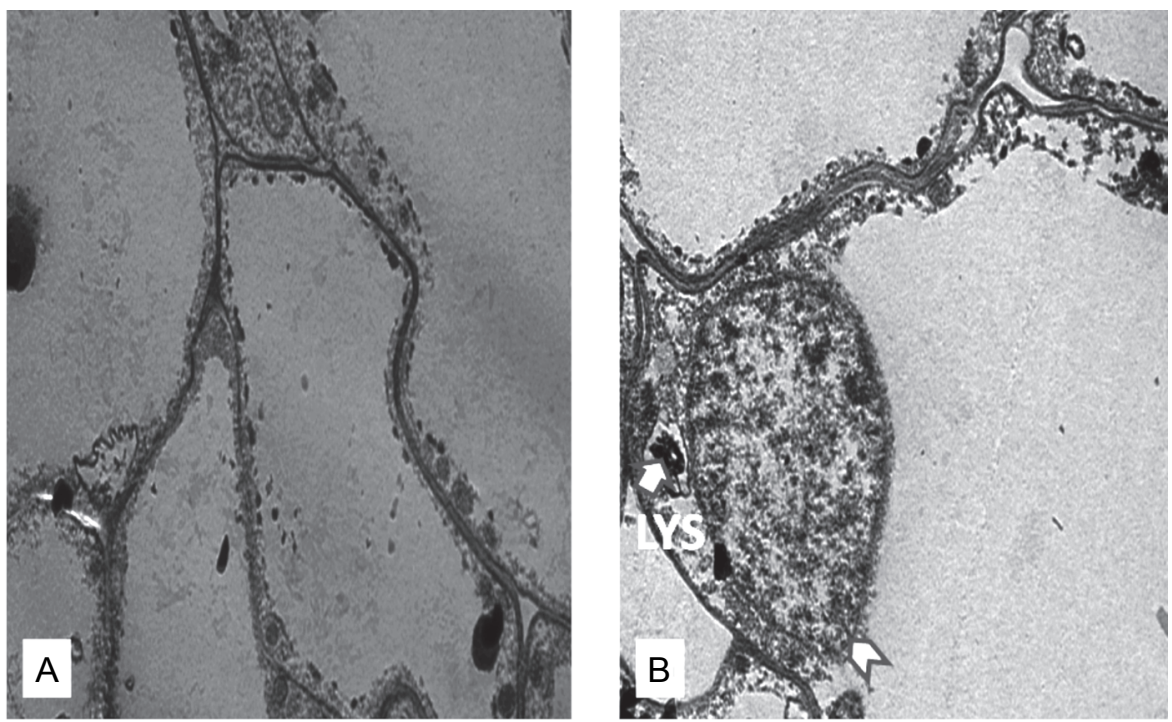

Fig. 6. TEM image of a brown callus A) cells devoid of cytoplasm and organelles, B) cell with lysosome (LYS) and a ruptured nuclear membrane marked with an arrow head

brown callus cells also showed the presence of a nucleus with nucleoli and heterochromatins, and other cell organelles including plastids, small Golgi bodies, starch granules, polyribosomes, a few round, and abundant elongated mitochondria, which are typical for cells with a high level of activity. According to Rebeiro et al. (2012), small Golgi bodies and elongated mitochondria are related to non-embryogenic cells.

On $10000 \times$ magnification, a large number of elongated mitochondria appeared adjacent to the cell wall and fully developed mitochondria with clearly visible cristae could be seen (Fig. 5B). This is of key importance for aerobic respiration, as mitochondria are structures where the electron transport and ATP synthesis reactions occur, which altogether suggests active cell metabolism. Rocha et al. (2012) reported that the presence of abundant mitochondria is characteristic for tissues undergoing differentiation. The plastids in the cells showed the presence of starch grains. Nakamura et al. (1994) stated that this biochemical pattern is a primary source of energy needed for intense cell division. Consumption of starch grains provides energy for callus development, which suggests an active regulation of the amount of starch in callus. Our results are similar to 
those of Aslam et al. (2011) and Steinmacher et al. (2011), who found cells with a well-developed nucleus and starch granules in callus cells of Bactrisgasipaes. Therefore, these results suggest that the non-brown callus cells show all the characteristics of an active nonembryogenic cell.

However, this was not the case with the brown callus whose sub cellular characteristics revealed by the TEM analysis was completely different from that of a nonbrown callus. The cells of brown callus were disorganized. Vacuoles, mitochondria, and other organelles could not be seen as they got completely decomposed (Fig. 6A). The cytoplasm of cells dissolved and some scattered cytoplasm could be seen only at peripheral regions near cell walls. The nucleus was found to have no nucleolus and the rupture of the nuclear membrane was clearly visible (Fig. 6B). Cells devoid of nucleolus are considered to be either dead or dying. The cells of the brown callus also revealed the presence of lysosomes. Lysosomes are small membrane-limited vesicles that contain 50-60 hydrolytic enzymes responsible for the destruction and digestion of cellular organelles, which is the ultimate response to cell starvation. We observed cellular alterations similar to those found during browning of the callus derived from Scots pine (Laukkanen et al., 1999) and sugarcane (Wang et al., 2016). Brown callus cells were highly plasmolyzed and often ruptured on examination.

\section{Conclusion}

The presented data suggest that the use of ascorbic acid and citric acid is an effective way to prevent callus tissue browning and it could have wide applications in tissue cultures of G. glabra where browning restricts callus development. There are reports insisting on the importance of non-embryogenic callus in the secondary metabolite production (Havsteen et al., 2002; Jedinak et al., 2004). In this study, electron microscopic observations showed clearly that the metabolically active nonembryogenic callus cultures are successfully established from leaf explants of G. glabra with optimum concentrations of plant growth regulators and antioxidants which resulted not only in establishment of a browning-free callus but also in obtaining healthy, proliferating callus cells having high metabolic activity that can further lead to effective metabolite production.

\section{Acknowledgements}

The authors are thankful to Dr. Sharma, Dr. Gajender Saini, and Dr. Ruchita Pal, the Advanced Instrumentation Research Facility (AIRF) and the University Science Instrumentation Center, JNU, New Delhi, for their support and assistance to carry out the TEM/SEM analysis of the samples.

\section{References}

Aslam J., Khan S. A., Cheruth A. J., Mujib A., Sharma M. P., Srivastava P.S. (2011) Somatic embryogenesis, scanning electron microscopy, histology and biochemical analysis at different developing stages of embryogenesis in six date palm (Phoenix dactylifera L.) cultivars. Saudi J. Biol. Sci. 18: 369-380.

Banerjee S., Upadhyay N., Kukreja A.K., Ahuja P.S., Kumar S., Saha G.C. (1996) Taxanes from in vitro cultures of the Himalayan yew Taxuswallichiana. Planta Medica 62: 329331.

Bradford M.M. (1976) A rapid and sensitive method for quantification of microgram quantities of protein utilizing the principle of protein-dye binding. Anal Biochem. 72: 248-254.

Canhoto J.M., Mesquita J.F., Cruz G.S. (1996) Ultrastructural changes in cotyledons of pineapple guava (Myrtaceae) during somatic embryogenesis. Ann. Bot. 78: 513-521.

Chaudhury A., Qu R. (2000) Somatic embryogenesis and plant regeneration of turf-type bermudagrass: effect of 6 -benzyladenine in callus induction medium. Plant Cell Tiss Org. 60: 113-120.

Dehon L., Macheix J.J., Durand M. (2002) Involvement of peroxidases in the formation of the brown coloration of heart wood in Juglans nigra. J. Exp. Bot. 53: 303-311.

Figueiredo M.A., Paiva R., Souza A.C., Porto J.M.P., Nogueira G.F., Soares F.P. (2007) Indução in vitro de calosemduase spécies de maracujazeironativo. Rev. Brasil. Biociên. 5: 288-290.

Flora S.J.S. (2009) Structural, chemical and biological aspects of antioxidants for strategies against metal and metalloid exposure. Oxid. Med. Cell Longev. 2: 191-206.

Fu C., Lei C., Gan L., Li M., Yang Y., Yu L. (2010) Optimization of embryogenic-callus induction and embryogenesis of Glycyrrhiza glabra. Afr. J. Biotechnol. 9: 5823-5829.

Habibi N., Suthar R.K., Purohit S.D. (2009) Role of PGrs and inhibitors in induction and control of somatic embryogenesis in Themedaquadrivalvis. Indian J. Exp. Biol. 47: 198-203.

Havsteen B.H. (2002) The biochemistry and medical significance of the flavonoids. Pharmacol. Ther. 96: 67-202.

He Y., Guo X., Lu R., Niu B., Pasapula V., Hou P., Cai F., Xu Y., Chen F. (2009) Changes in morphology and biochemical indices in browning callus derived from Jatropha curcas hypocotyls. Plant Cell Tiss. Organ. Cult. 9: 11-17.

Hossain M.J., Bari M.A., Ara N.A., Shahinulislam S.M. (2009) Effect of carbon sources on cell growth and regeneration ability in three cultivars of banana. J. Biosci. 17: 83-88. 
Huo Y.Q., Ge S.J., Men Y.J., Liu G.R. (2005) The progress of tissue culture of the Chinese liquorice (Glycyrrhiza uralensis Fisch.). Chin. Agric. Sci. Bull. 21: 64-66.

Jedinak A., Farao J., Psenakova I., Maliar T. (2004) Approaches to flavonoid production in plant tissue cultures. Biologia 59: 697-710.

Khosroushahi A.Y., Manesh H.N., Simonsen H.T. (2011) Effect of antioxidants and carbohydrates in callus cultures of $\mathrm{Ta}$ xusbrevifolia: evaluation of browning, callus growth, total phenolics and paclitaxel production. Bioimpacts 1: 37-45.

Laukkanen H., Häggman H., Kontunen-Soppela S., Hohtola A. (1999) Tissue browning of in vitro cultures of Scots pine. role of peroxidase and polyphenol oxidase. Physiol. Plant. 106: 337-343.

Mayer A., Harel E., Shaul R. (1965) Assay of catechol oxidase a critical comparison of methods. Physicochemistry 5: 783-789.

Mousa N., Siaguru P., Wiryowidagdo S., Wagih M.E (2006). Rapid clonal propagation of Licorice (Glycyrrhiza glabra) by in vitro. Sugar Technol. 8: 292-298.

Murashige T., Skoog F. (1962) A revised medium for rapid growth and bioassays with tobacco tissue cultures. Physiol. Plant. 15: 473-497.

Nakamura T., Taniguchi T., Maeda E. (1994) Cyto-histological studies on somatic embryos of Coffee: ultrastructural aspects. Japan. J. Crop Sci. 63: 144-157.

Ribeiro O., Paiva L.V., Pádua M.S., Santos B.R., Alves E., Stein V.C. (2012) Morphological and ultrastructural analysis of various types of banana callus, $c v$. Prata ana. Acta Sci. 34: 423-429.

Rocha D.I., Vieira L.M., Otoni W.C., Tanaka F.A.O., Da Silva L.C.(2012) Somatic embryogenesis of a wild passion fruit species Passiflora cincinnata Masters: Histological and histochemical evidences. Protoplasma 249: 747-758.
Sawaengsak W., Saisavoey T., Chuntaratin P., Karnchanatat A. (2011) Micropropagation of the medicinal herb Glycyrrhiza glabra L. through shoot tip explant culture and glycyrrhizin detection. Int. Res. J. Plant Sci. 2: 129-136.

Sharma P., Uppal S., Sehrawat A.R. (2005) Evaluation of callus cultures of Glycyrrhiza glabra L. var. HM 1 for glycyrrhizin. Nat. J. Plant Improv. 7: 62-64.

Steinmacher D.A., Guerra M.P., Saare-Surminski K., Leiberei R. (2011) A temporary immersion system improves in vitro regeneration of peach palm through secondary somatic embryogenesis. Ann. Bot. 108: 1-13.

Uddain J., Gnasekaran P., Zakaria L, Lynn C.B., Subramaniam S. (2015) The Effect of different growth media, Carbon source and PGRS on Dendrobium broga giant orchid's protocorm-like bodies (plbs) proliferation supported with SEM and TEM analysis. Pak. J. Bot. 47: 587-593.

Vijayalakshmi U., Shourie A. (2013) Gas ChromatographyMass spectrometric analysis of Glycyrrhiza glabra Linn. Roots. Int. J. Pharm. BioSci. 4: 741-755.

Vijayalakshmi U., Shourie A. (2015) Elicitor induced flavonoid production in callus cultures of Glycyrrhiza glabra and regulation of genes encoding enzymes of the phenyl propanoid pathway. Der Pharmacia Lett. 7: 156-166.

Wang M., Liao F., Yang L, Huang D.L., Yang L.T., Li Y.R. (2016) Influence factors and cell structure changes related to sugarcane stem tip browning in vitro culture. IJAIR 4: 768-772.

Wongwichaa W., Tanakab H., Shoyamac Y., Tuvshintogtokhd I., Putaluna W. (2008) Production of Glycyrrhizin in callus cultures of licorice journal of biosciences. Z. Naturforsch. C 63: 413-417.

Yu L.Q., He M.T., Wang Z.L., Xu Z.Y (1999) Study on techniques for rapid propagation of licorice (Glycyrrhiza uralensis Fiseh) by tissue culture. Grassland China 1: 12-14. 